\title{
MedChemComm
}

Broadening the field of opportunity for medicinal chemists rsc.li/medchemcomm

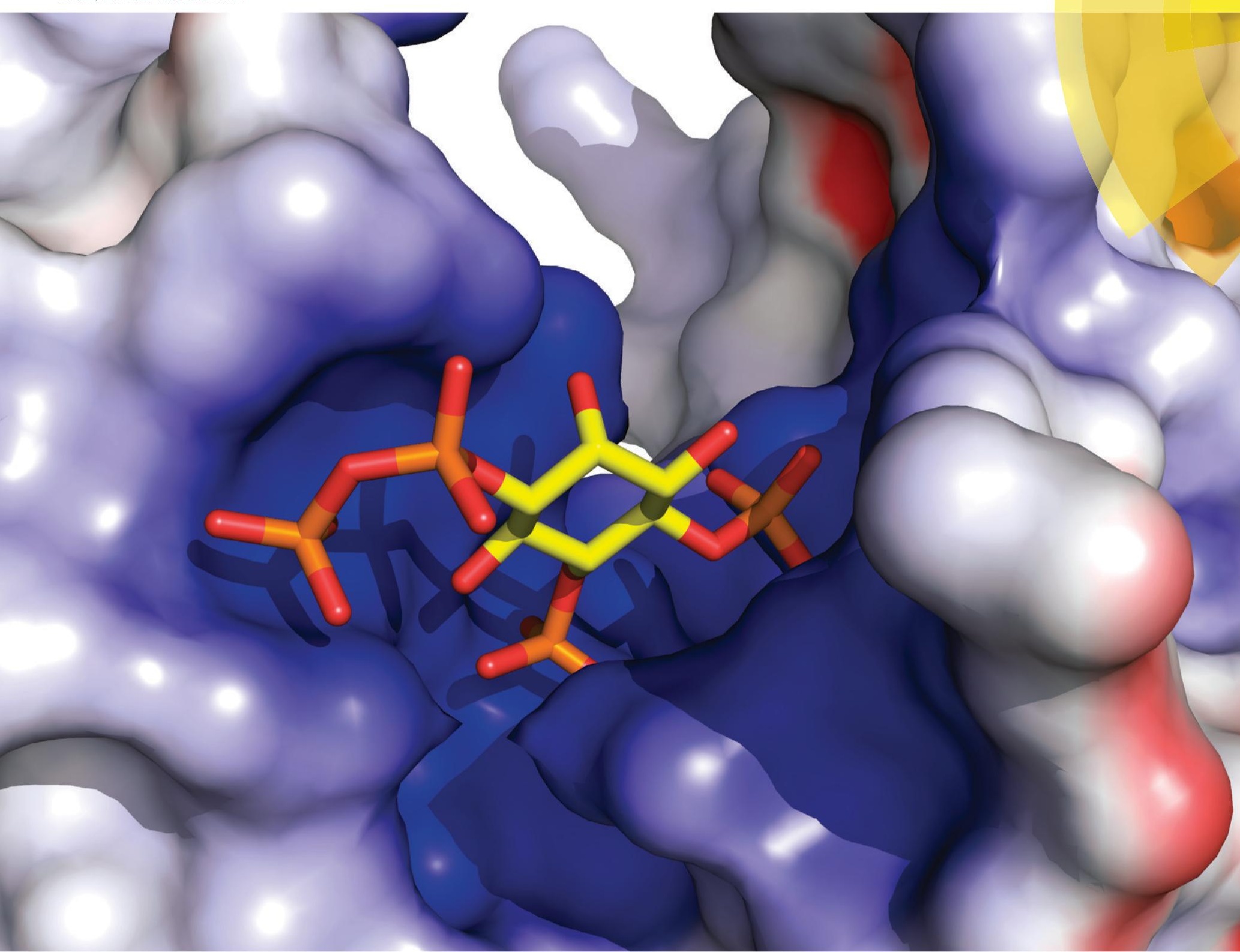

ISSN 2040-2511

A synthetic diphosphoinositol phosphate analogue of inositol trisphosphate
EFMC

European Federation

for Medicinal Chemistry 


\title{
MedChemComm
}

Check for updates

Cite this: Med. Chem. Commun. 2018, 9, 1105

Received 16th March 2018 ,

Accepted 1st May 2018

DOI: $10.1039 / \mathrm{c} 8 \mathrm{md} 00149 \mathrm{a}$

rsc.li/medchemcomm

\section{A synthetic diphosphoinositol phosphate analogue of inositol trisphosphate $\uparrow$}

\author{
Andrew M. Riley, (iD a Judith E. Unterlass, iD ${ }^{b}$ Vera Konieczny, ${ }^{c}$ Colin W. Taylor, (iD c \\ Thomas Helleday ${ }^{b}$ and Barry V. L. Potter (iD *a
}

\begin{abstract}
Diphosphoinositol phosphates (PP-InsPs) are inositol phosphates (InsPs) that contain PP (diphosphate) groups. Converting a phosphate group in an InsP into a diphosphate has been reported to enhance affinity for some binding proteins. We synthesised 1-PP- $\operatorname{Ins}(4,5) \mathrm{P}_{2}$, the first diphosphate analogue of the intracellular signalling molecule $\operatorname{Ins}_{3}$, and examined its effects on $\mathrm{InsP}_{3}$ receptors, which are intracellular $\mathrm{Ca}^{2+}$ channels. 1-PP-Ins $(4,5) \mathrm{P}_{2}$ was indistinguishable from $\operatorname{InSP}_{3}$ in its ability to bind to and activate type 1 Ins $\mathrm{P}_{3}$ receptors, indicating that the diphosphate modification of $\mathrm{InsP}_{3}$ affected neither affinity nor efficacy. Nevertheless, 1-PP-Ins $(4,5) \mathrm{P}_{2}$ is the most potent 1-phosphate modified analogue of Ins $\mathrm{P}_{3}$ yet identified. PP-InsPs are generally hydrolysed by diphosphoinositol polyphosphate phosphohydrolases (DIPPs), but 1-PPIns $(4,5) \mathrm{P}_{2}$ was not readily metabolised by human DIPPs. Differential scanning fluorimetry showed that 1-PP-Ins $(4,5) \mathrm{P}_{2}$ stabilises DIPP proteins, but to a lesser extent than naturally occurring substrates 1-PPIns $P_{5}$ and 5-PP-InsP $P_{5}$. The non-hydrolysable InsP $P_{7}$ analogues 1-PCP-InsP $P_{5}$ and 5-PCP-InsP $P_{5}$ showed comparable stabilising abilities to their natural counterparts and may therefore be promising substrate analogues for co-crystallisation with DIPPs.
\end{abstract}

\section{Introduction}

The myo-inositol phosphates (InsPs) are a family of intracellular signalling molecules containing monophosphate (P) and diphosphate (PP) groups arranged around the hexahydroxycyclohexane ring of myo-inositol (Ins). ${ }^{1}$ InsPs regulate many cellular processes, the best known being the release of $\mathrm{Ca}^{2+}$ from intracellular stores by D-myo-inositol 1,4,5-trisphosphate $\left(\mathrm{InsP}_{3}\right)$, which binds to receptors on the endoplasmic reticulum. ${ }^{2} \mathrm{InsP}_{3}$ is converted via a series of enzymatic phosphorylations ${ }^{3}$ into $\operatorname{InsP}_{6}$ (Fig. 1), which can then be further phosphorylated to give highly charged PP-InsPs containing diphosphate (pyrophosphate) groups. ${ }^{4,5}$

InsP $\mathrm{P}_{3}$ receptors $\left(\mathrm{IP}_{3} \mathrm{Rs}\right)$ are tetrameric intracellular $\mathrm{Ca}^{2+}$ channels, expressed in most animal cells. ${ }^{2}$ When $\operatorname{InsP}_{3}$ binds to the $N$-terminal InsP $_{3}$-binding core (IBC) of all four $\mathrm{IP}_{3} \mathrm{R}$

\footnotetext{
${ }^{a}$ Medicinal Chemistry and Drug Discovery, Department of Pharmacology, University of Oxford, Mansfield Road, Oxford OX1 3QT, UK. E-mail: barry.potter@pharm.ox.ac.uk; Fax: +44 (0)1865 271853; Tel: +44 (0)1865 271945

${ }^{b}$ Science for Life Laboratory, Department of Oncology-Pathology, Karolinska Institutet, SE-171 21 Solna, Sweden

${ }^{c}$ Department of Pharmacology, University of Cambridge, Tennis Court Road, Cambridge CB2 1PD, UK

$\dagger$ Electronic supplementary information (ESI) available: NMR spectra, additional DSF data and details of molecular docking experiments. See DOI: 10.1039/ c8md00149a
}

subunits, ${ }^{6}$ conformational changes propagate to the central pore. The pore then opens, allowing $\mathrm{Ca}^{2+}$ to flow into the cytosol, where it regulates many intracellular processes. The vicinal 4,5-bisphosphate structure of $\operatorname{InsP}_{3}$ is crucial (if not absolutely essential ${ }^{7}$ ) for activating $\mathrm{IP}_{3} \mathrm{Rs}$ because it cross-links the two domains of the clam-like IBC, pulling them together and initiating the conformational changes. The 1-phosphate group has a less direct, but enhancing, effect on activity. ${ }^{8}$

Although PP-InsP signalling is thought to be more evolutionarily ancient than $\operatorname{InsP}_{3}$-mediated mobilisation of $\mathrm{Ca}^{2+}$, much less is known about the functions and protein targets of PP-InsPs. Nevertheless, evidence is accumulating that PPInsPs play important roles at the interface of cell signalling and metabolism in the regulation of bioenergetic and phosphate homeostasis. ${ }^{4,5}$ Possible receptors for PP-InsPs include the $\mathrm{PH}$ (pleckstrin homology) domains ${ }^{10,11}$ and SPX (SYG1/ Pho81/XPR1) domains ${ }^{12,13}$ of proteins. PP-InsPs may also exert some of their effects by direct non-enzymatic diphosphorylation of target proteins. ${ }^{14}$

Phosphorylating a phosphate monoester in an $\operatorname{InsP}_{n}$ to give a PP-InsP ${ }_{n-1}$ not only increases the overall negative charge of the molecule, but also changes its shape, solvation and metal complexation properties. Unsurprisingly, therefore, a diphosphate group may alter ligand affinity for protein binding sites. ${ }^{4}$ For example, some $\mathrm{PH}$ domains that bind InsP $\mathrm{P}_{6}$ bind 5-InsP $\mathrm{P}_{7}$ with higher affinity, ${ }^{10,11}$ while 1 -Ins $\mathrm{P}_{7}$ and Ins $\mathrm{P}_{8}$ are weaker. ${ }^{11}$ In contrast, both 1 -Ins $\mathrm{P}_{7}$ and 5 -Ins $\mathrm{P}_{7}$ stimulate synthesis of inorganic polyphosphate (polyP) by the 


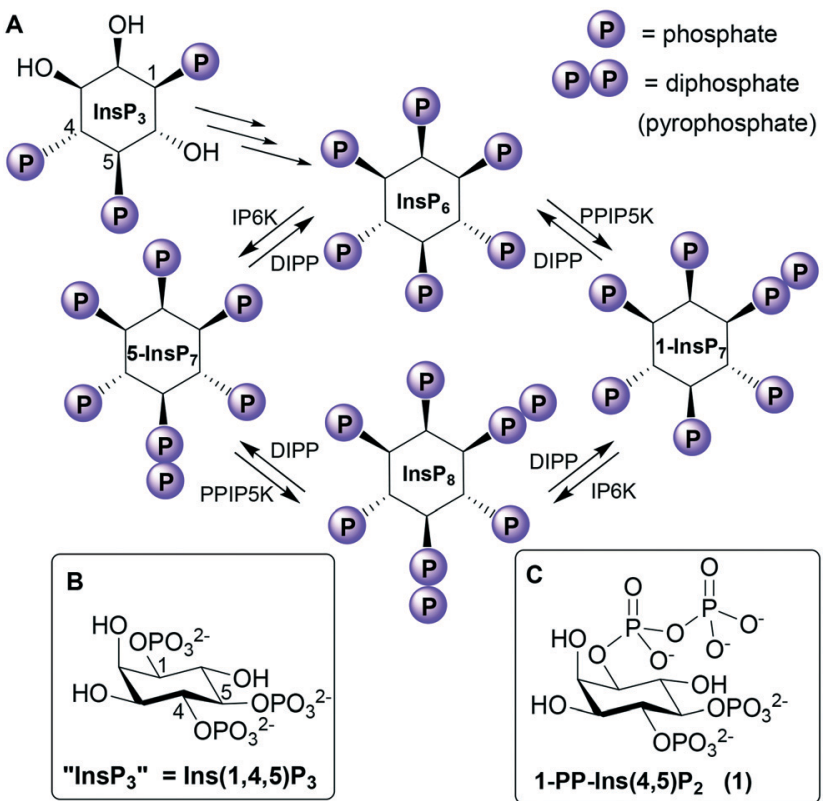

Fig. 1 A. Biosynthetic pathway connecting $\operatorname{Ins}(1,4,5) \mathrm{P}_{3}$ to the PPInsPs. IP6K, inositol hexakisphosphate 5-kinase; PPIP5K, diphosphoinositol pentakisphosphate kinase; DIPP, diphosphoinositol

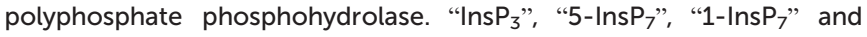
"InsP $\mathrm{P}_{8}$ " are alternative names for $\operatorname{Ins}(1,4,5) \mathrm{P}_{3}, 5-\mathrm{PP}-\operatorname{InsP}_{5}, 1-\mathrm{PP}-\operatorname{Ins} \mathrm{P}_{5}$ and $1,5-[P P]_{2}-\operatorname{lns} P_{4}$, respectively. B. Structure of $\operatorname{Ins}(1,4,5) P_{3}$. C. Structure of the synthetic analogue 1-PP- $\operatorname{Ins}(4,5) \mathrm{P}_{2}(1)$.

vacuolar transporter chaperone (VTC) by binding to its SPX domain, while $\operatorname{InsP}_{6}$ is inactive and $\mathrm{InsP}_{8}$ is 20 -fold more potent. ${ }^{13}$ PP-InsPs can be dephosphorylated back to InsPs by diphosphoinositol polyphosphate phosphohydrolases (DIPPs, Fig. 1), which specifically hydrolyse the diphosphate group, leaving a phosphate monoester and liberating inorganic phosphate. ${ }^{3,15}$

Given that introducing a diphosphate into an InsP may modify its interaction with proteins, we were interested in the possible effects of converting one of the phosphate groups in $\mathrm{InsP}_{3}$ into a diphosphate. The 1-phosphate group of InsP $\mathrm{P}_{3}$ has been a popular target for synthetic elaboration of $\mathrm{InsP}_{3}$ since early structure-activity studies showed that it is much more tolerant of modification than the 4- or 5-phosphate groups. ${ }^{8}$ Interest in the role of the 1-phosphate group was further stimulated by the discovery in 1993 of the adenophostins, fungal metabolites that are highly potent InsP $_{3}$ receptor ligands. ${ }^{16}$ The adenophostins contain a glucopyranoside 3,4-bisphosphate structure that mimics the myo-inositol 4,5-bisphosphate of $\operatorname{InsP}_{3}$ but intriguingly, their third phosphate group is located on a separate (ribofuranoside) ring, suggesting that repositioning this phosphate group may enhance affinity. ${ }^{17}$

The X-ray structure ${ }^{18}$ of the IBC of type 1 InsP $_{3}$ receptor bound to $\mathrm{InsP}_{3}$ confirmed the area of the binding pocket around the 1-phosphate of bound $\operatorname{InsP}_{3}$ to be relatively open. Our molecular docking experiments using this structure suggested that a 1-diphosphate should bind well to this region. We therefore set out to synthesise the 1-diphosphate an- alogue of $\mathrm{InsP}_{3}$, i.e. 1D-diphospho-myo-inositol 4,5bisphosphate [1-PP-Ins $(4,5) \mathrm{P}_{2}$ (1), Fig. 1] and examine its interaction with $\mathrm{InsP}_{3}$ receptors.

We were also interested to examine the interaction of 1-PP-Ins $(4,5) \mathrm{P}_{2}$ with DIPPs. Although DIPPs can hydrolyse the PP groups of highly phosphorylated PP-InsPs (Fig. 1), inorganic polyphosphate, 5-phosphoribosyl 1-pyrophosphate and nucleotide dimers, ${ }^{3,15}$ their catalytic mechanisms are poorly understood. 1-PP-Ins $(4,5) \mathrm{P}_{2}$ contains the target 1-PP structure found in the known DIPP substrate 1-PP-InsP ${ }_{5}$, but presented in the context of a molecule with only two phosphate monoester groups. There are no reports in the literature on whether "lower" PP-InsPs such as 1-PP-Ins $(4,5) \mathrm{P}_{2}$ could be recognised by the active sites of DIPPs.

\section{Results and discussion}

\section{Chemistry}

The synthesis of 1-PP-Ins $(4,5) \mathrm{P}_{2}(1)$ begins from the known alcohol 2 (ref. 19 and 20) (Scheme 1). To construct the diphosphate unit at $O-1$, we employed a modification of a recently described strategy, ${ }^{21,22}$ in which a temporarily protected phosphate group is introduced and then selectively deprotected to reveal a phosphate monoester. This phosphate is then phosphitylated to give a mixed $\mathrm{P}(\mathrm{III})-\mathrm{P}(\mathrm{v})$ anhydride, which is oxidised to a partially protected pyrophosphate unit. Removal of all protecting groups by catalytic hydrogenolysis then yields the target PP-InsP. We reasoned that it might be possible to employ methylsulfonylethyl (MSE) $)^{23,24}$ as a temporary phosphate protecting group in this sequence. The MSE group can be removed by $\beta$-elimination, similar to the betterknown $\beta$-cyanoethyl $(\beta \text {-CE })^{22,25}$ group. However, the MSE group is unaffected by catalytic hydrogenation, affording greater synthetic versatility, and the required phosphitylating reagent, phosphoramidite $\mathbf{5}$, is a stable crystalline solid.

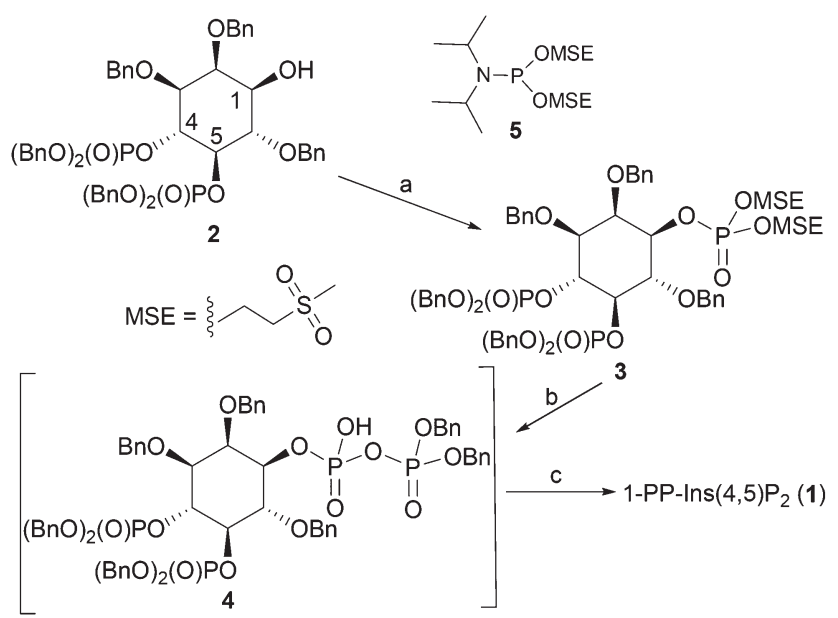

Scheme 1 Synthesis of $1-\mathrm{PP}-\operatorname{Ins}(4,5) \mathrm{P}_{2}$ (1). Reagents and conditions: a. i. 5-phenyl- $1 \mathrm{H}$-tetrazole, 5, $\mathrm{CH}_{2} \mathrm{Cl}_{2}$; ii. $m \mathrm{CPBA}, \mathrm{CH}_{2} \mathrm{Cl}_{2}, 89 \%$; b. i. $\mathrm{DBU}, \mathrm{BSTFA}, \mathrm{CDCl}_{3}$; ii. $\mathrm{MeOH}$, then TFA; iii. 5-phenyl-1H-tetrazole, $(\mathrm{BnO})_{2} \mathrm{PNPr}_{2}{ }_{2}, \mathrm{CH}_{2} \mathrm{Cl}_{2}$; iv. $m \mathrm{CPBA}, \mathrm{CH}_{2} \mathrm{Cl}_{2}, 90 \%$; c. i. $\mathrm{H}_{2}, \mathrm{Pd}(\mathrm{OH})_{2} / \mathrm{C}$, $\mathrm{MeOH}, \mathrm{H}_{2} \mathrm{O}, \mathrm{NaHCO}_{3}$; ii. lon-exchange chromatography on Q-Sepharose Fast Flow resin, 57\%. Bn, benzyl. 
Thus, the 1-OH group in 2 was reacted with 5 in the presence of 5-phenyl- $1 \mathrm{H}$-tetrazole to give an intermediate MSEprotected phosphite triester. Oxidation using mCPBA then gave 3, containing the MSE-protected phosphate triester at $O-1$. The diphosphate unit at $O-1$ was then constructed using a sequence of transformations carried out as described previously, ${ }^{21,22,25}$ with slight modifications. The progress of each step was carefully monitored by ${ }^{31} \mathrm{P}$ NMR spectroscopy (see Experimental section and ESI $\dagger$ ). The protected diphosphate 4 was found to be rather unstable and was immediately deprotected by catalytic hydrogenolysis at atmospheric pressure. A final purification step by gradient elution anion exchange chromatography on Q-Sepharose Fast Flow resin gave 1-PP-Ins $(4,5) \mathrm{P}_{2}(1)$ as the triethylammonium salt, which was accurately quantified by total phosphate assay.

\section{Interactions of 1-PP-Ins $(4,5) P_{2}$ with type $1 \operatorname{InsP}_{3}$ receptors}

Both InsP $\mathrm{P}_{3}$ and 1-PP-Ins $(4,5) \mathrm{P}_{2}$ (1) stimulated a concentrationdependent release of $\mathrm{Ca}^{2+}$ from the intracellular stores of permeabilised DT40 cells expressing type $1 \mathrm{InsP}_{3}$ receptors (Fig. 2A). The maximal $\mathrm{Ca}^{2+}$ release evoked by each ligand
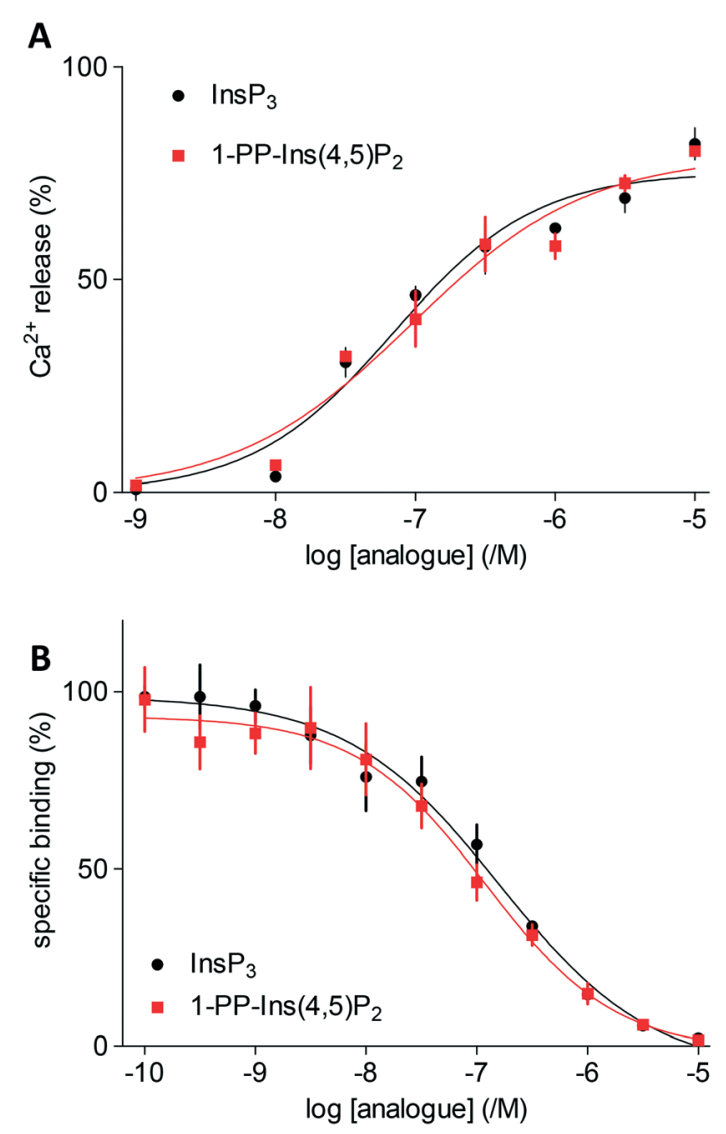

Fig. 2 A. $\mathrm{Ca}^{2+}$ release from intracellular stores of DT40 cells expressing type 1 InsP $\mathrm{P}_{3}$ receptors stimulated by $\operatorname{InsP}_{3}$ and 1-PPIns $(4,5) \mathrm{P}_{2}$ (1). Results are shown as $\%$ of $\mathrm{Ca}^{2+}$ content of intracellular stores. B. Equilibrium competition binding with ${ }^{3} \mathrm{H}-\mathrm{InsP} \mathrm{P}_{3}$ and $\operatorname{lns} \mathrm{P}_{3}$ or 1-PP-Ins $(4,5) P_{2}$ (1) using membranes from Sf9-IP ${ }_{3} R 1$ cells in CLM containing $1.5 \mathrm{mM}$ MgATP. Results are means \pm s.e.m., $n=3$. and the half-maximally effective concentration $\left(\mathrm{EC}_{50}\right)$ were similar for 1 and $\operatorname{InsP}_{3}$ (Fig. 2A). Membranes from Sf9 cells expressing rat type $1 \operatorname{InsP}_{3}$ receptors were used for equilibrium competition binding studies with ${ }^{3} \mathrm{H}-\mathrm{Ins} \mathrm{P}_{3}$, because these membranes express full-length type $1 \mathrm{InsP}_{3}$ receptors at $\sim 20$-fold higher levels than cerebellar membranes, the richest endogenous source. The experiments were carried out in cytosol-like medium (CLM, pH 7.3) containing $1.5 \mathrm{mM}$ $\mathrm{Mg}$-ATP to match the conditions used for $\mathrm{Ca}^{2+}$-release assays.

In agreement with the $\mathrm{Ca}^{2+}$-release assays, 1-PP-Ins $(4,5) \mathrm{P}_{2}$ (1) bound with the same affinity as $\mathrm{InsP}_{3}$ to $\mathrm{InsP}_{3}$ receptors (Fig. 2B). Thus, the two compounds were essentially indistinguishable in both functional and binding assays (Table 1). Rapid chemical hydrolysis of $\mathbf{1}$ could in principle explain the similar behaviour of $\operatorname{InsP}_{3}$ and 1 , but we saw no evidence that 1 is unstable. The ${ }^{31} \mathrm{P}$ NMR spectrum of 1 in $\mathrm{D}_{2} \mathrm{O}$ (see ESI $\dagger$ ) was unchanged after the sample solution had been kept for several days at room temperature, followed by one year at $4^{\circ} \mathrm{C}$.

Molecular docking experiments (see Experimental section and $\mathrm{ESI} \dagger$ for details) using the X-ray crystal structure of the IBC of type $1 \mathrm{InsP}_{3}$ receptor ${ }^{18}$ suggested that the diphosphate group in 1 should be well-tolerated by the $\operatorname{InsP}_{3}$-binding pocket and may be capable of forming additional hydrogen bonds with residues in the binding site (Fig. 3). Nevertheless, it is well known that attempts to optimise drug candidates by adding polar groups may fail because the expected enthalpic gains from new polar interactions are opposed by ligand desolvation penalties and unfavourable entropic effects, resulting in no gain in binding affinity. ${ }^{26}$ Such compensatory effects may underlie the similar affinities of 1 and $\operatorname{InsP}_{3}$ for type $1 \mathrm{InsP}_{3}$ receptors.

\section{Interaction of 1-PP-Ins $(4,5) \mathrm{P}_{2}$ with DIPPs}

The dephosphorylation of PP-InsPs is catalysed by diphosphoinositol polyphosphate phosphohydrolases (DIPPs), which selectively cleave the diphosphate (PP) to give a phosphate monoester and inorganic phosphate (Pi). ${ }^{3}$ Humans express four DIPP types: DIPP-1 is the product of the NUDT3 gene; DIPP-2 (of which there are two isoforms, DIPP- $2 \alpha$ and DIPP-2 $\beta$, produced by alternative splicing) is the product of NUDT4; DIPP-3 $\alpha$ is the product of NUDT10 and DIPP-3 $\beta$ is the product of NUDT11. ${ }^{3}$ We examined the interaction of 1-PP-Ins $(4,5) \mathrm{P}_{2}(1)$ with all four DIPPs in comparison

Table 1 Interactions of $\operatorname{Ins} \mathrm{P}_{3}$ and $1-\mathrm{PP}-\operatorname{Ins}(4,5) \mathrm{P}_{2}$ (1) with type $1 \operatorname{lns} \mathrm{P}_{3}$ receptors $(n=3)$

\begin{tabular}{lllllll}
\hline & \multicolumn{3}{c}{$\mathrm{Ca}^{2+}$ release } & & \multicolumn{3}{c}{ Binding $^{a}$} \\
\cline { 2 - 3 } & & $\mathrm{pEC}_{50} / \mathrm{M}$ & $\mathrm{EC}_{50} / \mathrm{nM}$ & release & $\mathrm{p} K_{\mathrm{d}} / \mathrm{M}$ & $K_{\mathrm{d}} / \mathrm{nM}$ \\
\hline $\operatorname{InsP}_{3}$ & $7.21 \pm 0.08$ & 62 & $82 \pm 4$ & $6.89 \pm 0.07$ & 128 \\
$1-\mathrm{PP}-\operatorname{Ins}(4,5) \mathrm{P}_{2}(1)$ & $7.17 \pm 0.11$ & 68 & $80 \pm 1$ & $6.96 \pm 0.05$ & 110
\end{tabular}

${ }^{a}$ Binding was done using Sf9 cell membranes overexpressing rat type 1 InsP $_{3}$ receptors in CLM ( $\mathrm{pH}$ 7.3) containing $1.5 \mathrm{mM} \mathrm{Mg-ATP}$ to match the conditions used in the $\mathrm{Ca}^{2+}$ release assay. 

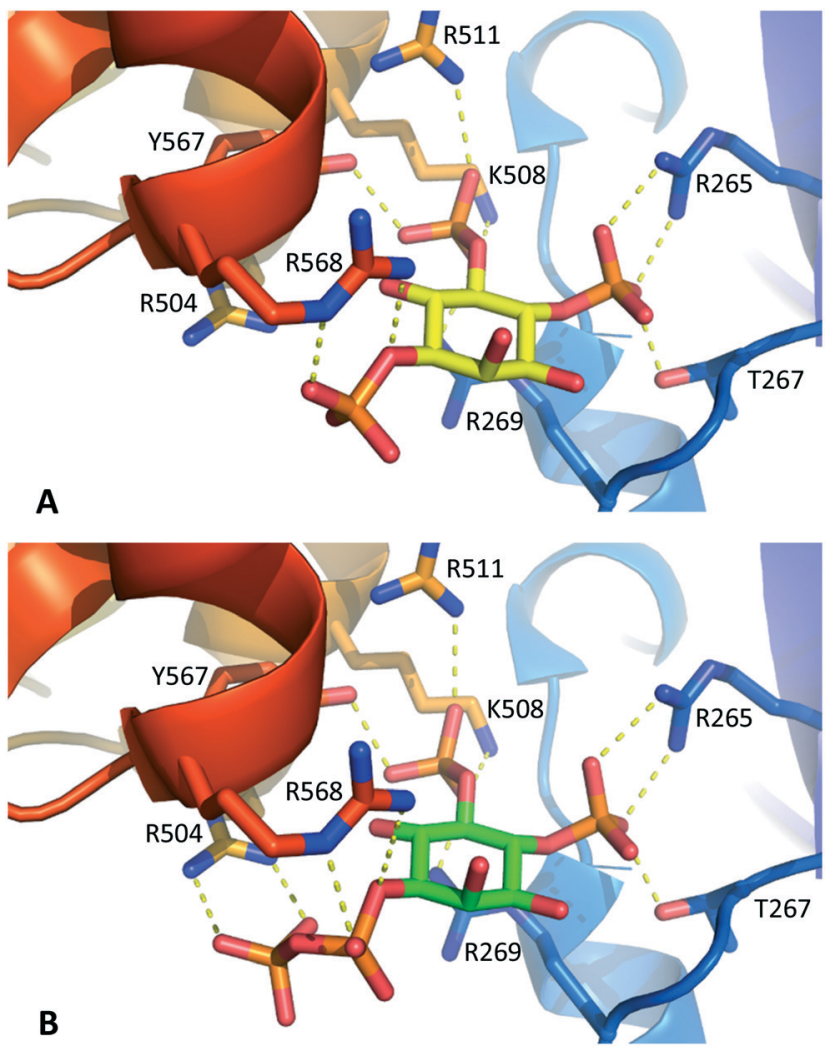

Fig. 3 A. Interactions of $\operatorname{Ins}_{3}$ with the IBC of type $1 \operatorname{lns} \mathrm{P}_{3}$ receptors, based on the X-ray crystal structure of $I_{3} R 1$ in complex with $I n s P_{3}$ (ref. 18) (1N4K). B. Model of 1-PP-Ins $(4,5) \mathrm{P}_{2}$ (1) in the IBC produced by molecular docking (see Experimental section and ESI† for details). For clarity, water molecules are not shown.

with two naturally-occurring substrates 1-PP-InsP ${ }_{5}$ and 5-PPInsP $_{5}$ ("1-InsP" and " 5 -InsP $P_{7}$ ", respectively) and also with the alternative substrates diadenosine polyphosphates $\mathrm{Ap}_{3} \mathrm{~A}$ and $\mathrm{Ap}_{5} \mathrm{~A}$. Non-hydrolysable $\mathrm{InsP}_{7}$ analogues 1-PCP-InsP ${ }_{5}$ (ref. 27) and 5-PCP-InsP ${ }_{5}$ (ref. 28) were independently synthesised and included as controls.

With $\mathrm{Mg}^{2+}$ present in the buffer, 1-PP-InsP $\mathrm{P}_{5}$ and 5-PP-InsP ${ }_{5}$ were rapidly metabolised by all four DIPPs (Fig. 4A). The rate of hydrolysis of 1-PP-InsP ${ }_{5}$ was significantly higher than that for 5-PP-InsP ${ }_{5}$ in each case. This finding is in agreement with a previous study. ${ }^{15}$ As expected, the PCP analogues were not metabolised, confirming that DIPPs can hydrolyse only the diphosphate unit and not the phosphate monoesters. $\mathrm{Ap}_{3} \mathrm{~A}$ and $\mathrm{Ap}_{5} \mathrm{~A}$ were unaffected by all four enzymes in $\mathrm{Mg}^{2+}$-containing buffer, an observation that had been reported for NUDT10 and NUDT11, but not for NUDT3 and NUDT4. ${ }^{29}$ Perhaps surprisingly, 1-PP-Ins $(4,5) \mathrm{P}_{2}(1)$ was also not metabolised under these conditions. The presence of a divalent cation is required for the activity of NUDT10 and NUDT11 and also for NUDT3. ${ }^{3}$ When $\mathrm{Mg}^{2+}$ in the buffer was replaced by $\mathrm{Mn}^{2+}, 1$ was now hydrolysed by the DIPPs, while 1-PP-InsP ${ }_{5}$ and 5 -PP-InsP ${ }_{5}$ resisted hydrolysis. In addition, $\mathrm{Ap}_{5} \mathrm{~A}$ now also behaved as a substrate for all four DIPPs (Fig. 4B). In the absence of enzyme none of the compounds, including 1 , showed any sign of hydrolysis during the time course of the experiment in the pres- ence of either $\mathrm{Mg}^{2+}$ or $\mathrm{Mn}^{2+}$-containing buffers. This further supports our conclusion above that $\mathbf{1}$ was not hydrolysed to InsP $\mathrm{P}_{3}$ during the $\mathrm{InsP}_{3}$ receptor assays.

Next, we used differential scanning fluorimetry (DSF) to measure the ability of the compounds to stabilise NUDT3 (DIPP1). While the effects of $\mathrm{Ap}_{3} \mathrm{~A}$ and $\mathrm{Ap}_{5} \mathrm{~A}$ were not significantly different from control (Fig. 5A), 1-PP-Ins(4,5) $\mathrm{P}_{2}$ (1) raised the melting temperature $\left(T_{\mathrm{m}}\right)$ of NUDT3 by approx. $5{ }^{\circ} \mathrm{C}$ at a concentration of $0.1 \mathrm{mM}$. As expected, the more highly phosphorylated 1-PP-InsP ${ }_{5}$ had much stronger effects, resulting in a $T_{\mathrm{m}}$-shift of $20-25{ }^{\circ} \mathrm{C}$. Similar DSF experiments were then carried out for NUDT4, NUDT10 and NUDT11. $\mathrm{Ap}_{3} \mathrm{~A}$ did not stabilise any of the DIPPs, which supports our results for the activity assay. The results are summarised in Fig. 5B.

We obtained further DSF data over a range of ligand concentrations for 1-PP-InsP $P_{5}$ and 1-PP-Ins $(4,5) \mathrm{P}_{2} \quad$ (1), constructing dose-response curves for the two compounds (Fig. 6). It is interesting to note that the effect of 1 on NUDT10 was significantly lower compared to the other DIPPs and especially compared to NUDT11 (Fig. 6B). NUDT10 and NUDT11 have identical protein sequences apart from residue 89 , which is either proline (NUDT10) or arginine (NUDT11).

Noting the strong stabilisation of all the proteins by the PCP analogues, we obtained further DSF data over a range of ligand concentrations for 1-PCP-InsP $\mathrm{P}_{5}$ and 5 -PCP-InsP ${ }_{5}$ (ESI $†$ Fig. S4 and S5) and calculated $K_{\mathrm{D}}$ values from these curves (ESI $\uparrow$ Tables S1 and S2). We found that, in some cases, the PCP analogues had binding affinities comparable to those of their natural PP-containing ligands.

\section{Conclusions}

Replacing a phosphate group in an inositol phosphate ligand with a diphosphate (PP) group can modify the interaction of the ligand with target proteins. ${ }^{10-13}$ Structure-activity studies have previously shown that the 1-phosphate group of $\operatorname{InsP}_{3}$ is amenable to synthetic modification, and molecular docking experiments suggested that a 1-diphosphate group should be well-tolerated by the binding site of the $\mathrm{InsP}_{3}$ receptor. We therefore synthesised 1-PP-Ins $(4,5) \mathrm{P}_{2} \quad(1)$, the first PPcontaining analogue of $\mathrm{InsP}_{3}$. Using assays of $\mathrm{Ca}^{2+}$-release through type $1 \mathrm{InsP}_{3}$ receptors, we found that 1 was equipotent to $\mathrm{InsP}_{3}$ and in binding assays its affinity was indistinguishable from that of $\operatorname{InsP}_{3}$. Thus, the 1-diphosphate modification of InsP $\mathrm{P}_{3}$ does not affect its affinity for or activity at type $1 \mathrm{InsP}_{3}$ receptors. Nevertheless, 1 is the first $\mathrm{Ca}^{2+}$-releasing PP-InsP and also the most potent P-1 modified ligand of InsP $_{3}$ receptors yet identified.

The novel diphosphate compound 1 was not metabolised by DIPPs in the presence of $\mathrm{Mg}^{2+}$-containing buffer, while the naturally-occurring $\mathrm{InsP}_{7}$ isomers, 5-PP-InsP $\mathrm{P}_{5}$ and 1-PP-InsP ${ }_{5}$

\$ A synthetic $\mathrm{InsP}_{3}$ derivative featuring 4-carboxy-malachite green conjugated to the 1-phosphate group was reported to have $\sim 170$-fold higher affinity than $\operatorname{InsP}_{3}$ for an $\mathrm{N}$-terminal fragment of type $1 \mathrm{InsP}_{3}$ receptors. ${ }^{43}$ In our hands, this compound was $\sim 5$-fold less potent than $\mathrm{InsP}_{3}$ at each $\mathrm{InsP}_{3}$ receptor subtype and had an affinity $\sim 7$-fold less than $\mathrm{InsP}_{3}$ for type $1 \mathrm{InsP}_{3}$ receptors. ${ }^{44}$ 
A

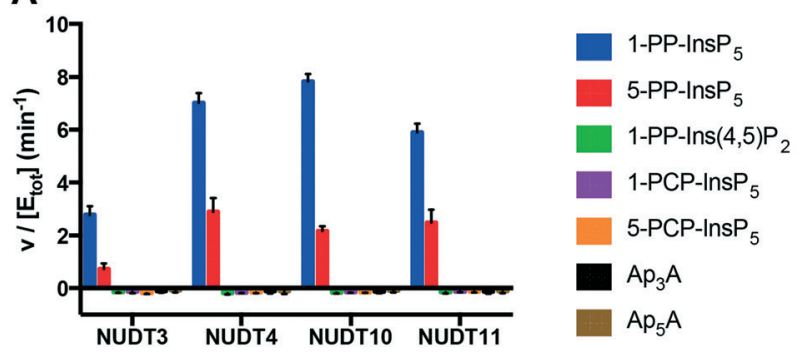

C

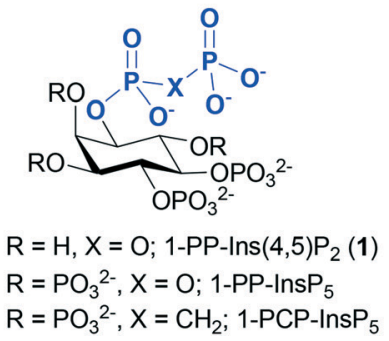

B

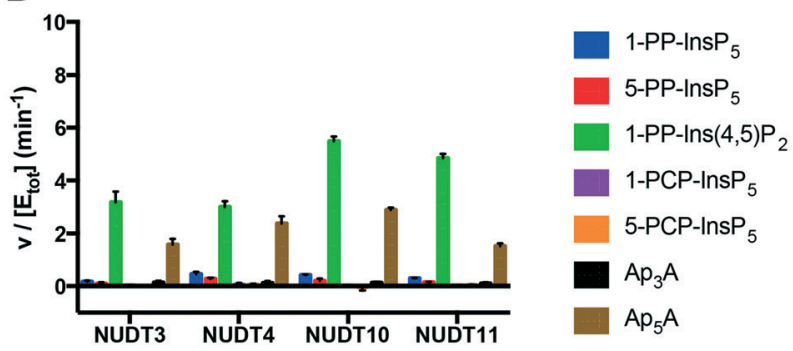

were rapidly hydrolysed. Conversely, in the presence of $\mathrm{Mn}^{2+}$, 1 was hydrolysed while the two $\mathrm{InsP}_{7}$ isomers were unaffected. Synthetic PCP-containing analogues of the $\mathrm{InsP}_{7} \mathrm{~S}$ were

\section{A}

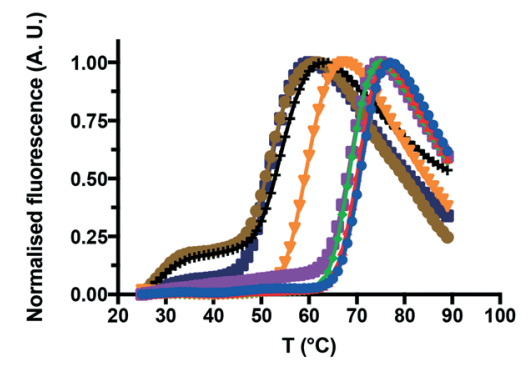

$$
\begin{aligned}
& -1-P P-I n s P_{5} \\
& 5-P P-I n s P_{5} \\
\rightarrow & 1-P C P-I n s P_{5} \\
& 5-P C P-I n s P_{5} \\
& 1-P P-\operatorname{lns}(4,5) P_{2}(1) \\
& -A_{5} A \\
& -A_{3} \mathrm{~A} \\
& -\mathrm{H}_{2} \mathrm{O} \text { control }
\end{aligned}
$$

B

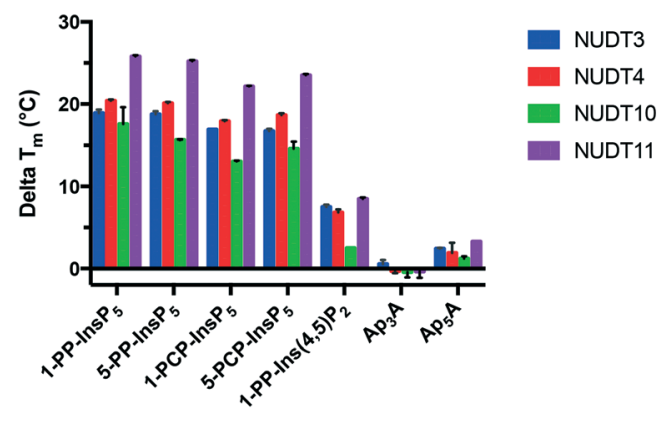

$0.1 \mathrm{mM}$ substrate

Fig. 5 A. Effect of 1-PP- $\operatorname{Ins}(4,5) \mathrm{P}_{2}(1)$ and other compounds shown in Fig. $4 \mathrm{C}$ on the melting temperature $\left(T_{\mathrm{m}}\right)$ of NUDT3, measured using differential scanning fluorimetry (DSF). B. Comparison of melting temperature shifts (delta $T_{m}$ ) induced by all compounds for all four DIPPs examined. not hydrolysed under any conditions examined, but when evaluated for their ability to stabilise DIPP proteins using differential scanning fluorimetry (DSF), they gave temperature shifts comparable to their natural PP-containing equivalents.

A

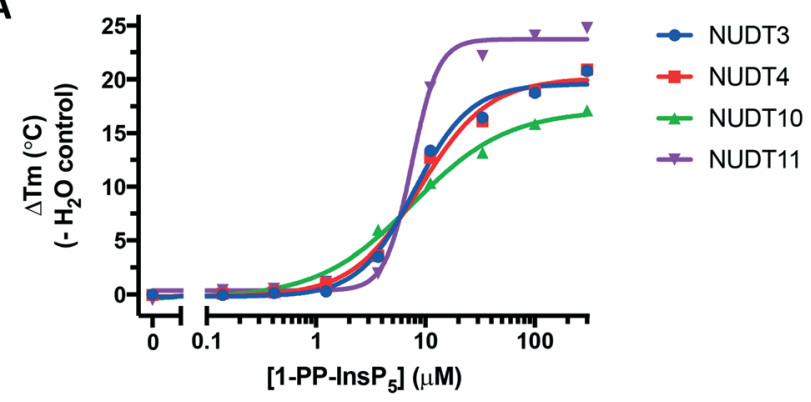

B

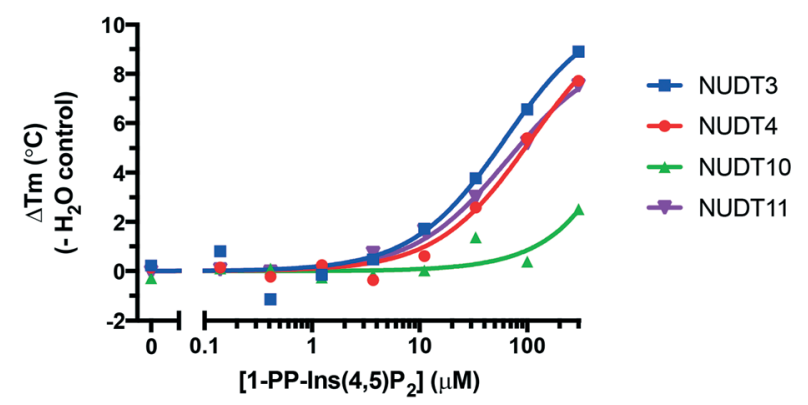

Fig. 6 Dose-response curves showing stabilisation of all four DIPPs by A. 1-PP-InsP $P_{5}$ and B. 1-PP- $\operatorname{lns}(4,5) P_{2}$ (1). Note the different $y$-axis scales in $A$ and $B$. 
This strongly suggests that 1-PCP-InsP $\mathrm{P}_{5}$ and 5 -PCP-InsP $\mathrm{P}_{5}$ could be promising ligands for co-crystallisation studies with DIPPs.

Could 1-PP-Ins $(4,5) \mathrm{P}_{2}$ be an endogenous molecule? The mammalian enzymes known to synthesise PP-InsPs are 5-diphosphoinositol pentakisphosphate kinases (PPIP5Ks) and inositol hexakisphosphate kinases (IP6Ks). Inositol phosphate multikinase (IPMK) has also been reported to synthesise PP-InsP $\mathrm{P}_{4}$ from InsP $_{5}$ in vitro, ${ }^{30}$ but the products of InsP $_{3}$ phosphorylation by IPMK are $\operatorname{Ins}(1,3,4,5) \mathrm{P}_{4}$ and/or Ins $(1,4,5,6) \mathrm{P}_{4} \cdot{ }^{31}$ Phosphorylation of lower InsPs by PPIP5Ks seems unlikely, considering the constraints of the catalytic site $^{32}$ and the recently discovered capture site; ${ }^{22}$ even Ins $(1,3,4,5,6) \mathrm{P}_{5}$ is not phosphorylated. ${ }^{32}$ Recombinant Kcs1p, a yeast homologue of IP6K1, was reported to phosphorylate InsP $_{3}$ slowly, although the identities of the products could not be determined. ${ }^{33}$ Later work confirmed that $\operatorname{InsP}_{3}$ was phosphorylated by Kcs1 and the product was identified as Ins $(1,3,4,5) \mathrm{P}_{4}$ (i.e. in this case, Kcs1 functioned as a 3-kinase). ${ }^{34}$ More recently, a study found that EhIP6KA, an IP6K homologue from Entamoeba histolytica, was capable of slowly phosphorylating InsP $\mathrm{P}_{3}$, although the products were identified as Ins $(1,4,5,6) \mathrm{P}_{4}$ and $\operatorname{Ins}(1,2,4,5) \mathrm{P}_{4} \cdot{ }^{35}$ On this basis, naturally occurring 1-PP-Ins $(4,5) \mathrm{P}_{2}$ seems unlikely. However, in both studies where the identities of the enzyme products were assigned, ${ }^{34,35}$ resistance to hydrolysis by DIPP1 was used to exclude the possibility that the products contained diphosphate groups. The present work shows that this criterion may not always be valid; in our hands, 1-PP-Ins $(4,5) \mathrm{P}_{2}$ was not metabolised in the presence of $\mathrm{Mg}^{2+}$ by any of the DIPPs, yet it does contain a diphosphate group.

Notwithstanding the evidence for PP-InsPs playing physiological roles, ${ }^{4,5}$ the present work indicates that a physiological function for 1-PP-Ins $(4,5) \mathrm{P}_{2}$, at least in relation to the regulation of $\mathrm{InsP}_{3}$ receptor-mediated $\mathrm{Ca}^{2+}$ release, may be unlikely. Converting the 1-phosphate of $\mathrm{InsP}_{3}$ into a diphosphate neither attenuates nor enhances the ability of the ligand to activate $\operatorname{InsP}_{3} \mathrm{R}$. As the first example of a diphosphate analogue of a second messenger, however, the results add a new component to structure-activity relationships. Cocrystallisation studies with DIPPs using some of the nonhydrolysable substrate analogues discussed here are currently in progress.

\section{Experimental}

\section{General chemistry methods}

General methods were as previously reported. ${ }^{36}$ Alcohol $2=$ 1D-2,3,6-tri-O-benzyl-myo-inositol 4,5-bis-O-(dibenzylphosphate) was synthesised according to the literature ${ }^{19}$ and crystallised from diethyl ether/light petroleum; m.p. 90-91 ${ }^{\circ} \mathrm{C}$; Lit. $^{19}$ 90$91{ }^{\circ} \mathrm{C} ;[\alpha]_{\mathrm{D}}^{20}=-18.2,\left(c=2, \mathrm{CHCl}_{3}\right)$, Lit. $^{19}[\alpha]_{\mathrm{D}}^{25}=-15.6,(c=1$, $\left.\mathrm{CHCl}_{3}\right)$; Lit. $^{20}[\alpha]_{\mathrm{D}}^{20}=-17.8,\left(c=1.7, \mathrm{CHCl}_{3}\right) . \quad N, N-$ Diisopropylamino-bis-[2-(methylsulfonyl)ethyloxy]-phosphine (5) was synthesised according to the literature ${ }^{24}$ and recrystallized from dichloromethane/ether; m.p. $75.5-77.0^{\circ} \mathrm{C}$;
${ }^{1} \mathrm{H}$ NMR $\left(\mathrm{CDCl}_{3}, 400 \mathrm{MHz}\right) \delta 1.20\left(12 \mathrm{H}, \mathrm{d},{ }^{3} J_{\mathrm{HP}} 6.8 \mathrm{~Hz}, 4 \times\right.$ $\left.\mathrm{CHCH}_{3}\right), 3.01\left(6 \mathrm{H}, \mathrm{s}, 2 \times \mathrm{SCH}_{3}\right), 3.22-3.34(4 \mathrm{H}, \mathrm{m}, 2 \times$ $\left.\mathrm{OCH}_{2} \mathrm{CH}_{2} \mathrm{~S}\right), 3.59\left(2 \mathrm{H}, \mathrm{dh},{ }^{3} J_{\mathrm{HP}} 10.4 \mathrm{~Hz},{ }^{3} J_{\mathrm{HH}} 6.8 \mathrm{~Hz}, 2 \times\right.$ $\left.\mathrm{CHCH}_{3}\right), 4.01-4.15\left(4 \mathrm{H}, \mathrm{m}, 2 \times \mathrm{OCH}_{2} \mathrm{CH}_{2} \mathrm{~S}\right) ;{ }^{13} \mathrm{C} \mathrm{NMR}\left(\mathrm{CDCl}_{3}\right.$, $101 \mathrm{MHz}) \delta 24.62\left({ }^{3} J_{\mathrm{CP}} 7.3 \mathrm{~Hz}, 4 \times \mathrm{CHCH}_{3}\right), 42.85\left(2 \times \mathrm{SCH}_{3}\right)$, $43.31\left({ }^{2} J_{\mathrm{CP}} 12.4 \mathrm{~Hz}, 2 \times \mathrm{CHCH}_{3}\right), 56.17\left({ }^{3} J_{\mathrm{CP}} 8.3 \mathrm{~Hz}, 2 \times\right.$ $\left.\mathrm{OCH}_{2} \mathrm{CH}_{2} \mathrm{~S}\right), 57.58\left({ }^{2} J_{\mathrm{CP}} 20.0 \mathrm{~Hz}, 2 \times \mathrm{OCH}_{2} \mathrm{CH}_{2} \mathrm{~S}\right) ;{ }^{31} \mathrm{P} \mathrm{NMR}$ $\left(\mathrm{CDCl}_{3}, 162 \mathrm{MHz},{ }^{1} \mathrm{H}\right.$-decoupled) $\delta$ 148.98; HRMS (m/z) $[\mathrm{M}+$ $\mathrm{H}]^{+}$calcd. for $\mathrm{C}_{12} \mathrm{H}_{28} \mathrm{O}_{6} \mathrm{NPS}_{2} ; 378.11684$; found 378.11687 . 5-PP-InsP $\mathrm{P}_{5}$, 1-PP-InsP $\mathrm{P}_{5}$ and their PCP analogues were synthesised using similar methods to those previously described. $21,22,27,28,36$

D-2,3,6-tri-O-Benzyl-myo-inositol-4,5-bis(dibenzylphosphate)1-bis[2-(methylsulfonyl)ethyl]phosphate (3). To a solution of alcohol 2 (194 mg, $0.200 \mathrm{mmol})$ in dry dichloromethane $(3 \mathrm{~mL})$ was added 5-phenyl- $1 \mathrm{H}$-tetrazole $(64 \mathrm{mg}, 0.44 \mathrm{mmol})$ and $\mathrm{N}, \mathrm{N}$ diisopropylamino-bis-[2-(methylsulfonyl)ethyloxy]-phosphine (5) $(130 \mathrm{mg}, 0.344 \mathrm{mmol})$. The suspension was stirred under $\mathrm{N}_{2}$ at room temperature for $2 \mathrm{~h}$, after which time TLC (dichloromethane: ethyl acetate $1: 1$ ) showed total conversion of $2\left(R_{\mathrm{f}} 0.56\right)$ into a more polar product $\left(R_{\mathrm{f}} 0.24\right)$. The mixture was then cooled to $-78^{\circ} \mathrm{C}$, before $m \mathrm{CPBA}(70 \%, 100 \mathrm{mg}, 0.406$ $\mathrm{mmol}$ ) was added. The mixture was allowed to warm to room temperature and then diluted with EtOAc $(30 \mathrm{~mL})$. The clear, colourless solution was washed with $10 \%$ aq. $\mathrm{Na}_{2} \mathrm{SO}_{3}$ solution $(2 \times 30 \mathrm{~mL})$ and 1.0 mold per $\mathrm{m}^{3} \mathrm{HCl}(30 \mathrm{~mL})$, then dried over $\mathrm{MgSO}_{4}$ and concentrated. The residue was purified by flash chromatography on silica, eluting with methanol in ethyl acetate (0 to $15 \%$ ) to give 3 as a colourless oil $(225 \mathrm{mg}, 0.178$ mmole, 89\%); TLC (ethyl acetate: methanol 10:1): $R_{\mathrm{f}}=0.50$; $[\alpha]_{\mathrm{D}}^{20}=-10.3,\left(c=1.4, \mathrm{CHCl}_{3}\right) ;{ }^{1} \mathrm{H} \mathrm{NMR}\left(\mathrm{CDCl}_{3}, 400 \mathrm{MHz}\right) \delta 2.76$ ( $\left.3 \mathrm{H}, \mathrm{s}, \mathrm{SCH}_{3}\right), 2.82\left(3 \mathrm{H}, \mathrm{s}, \mathrm{SCH}_{3}\right), 2.79-2.87(1 \mathrm{H}, \mathrm{m}$, $\mathrm{OCH}_{2} \mathrm{CHCHS}$ ), 2.92-3.00 (1 H, m, $\mathrm{OCH}_{2} \mathrm{CHCHS}$ ), 3.03-3.13 (2 $\left.\mathrm{H}, \mathrm{m}, 2 \times \mathrm{OCH}_{2} \mathrm{CHCHS}\right), 3.62(1 \mathrm{H}, \mathrm{dd}, J 9.8,1.9 \mathrm{~Hz}, \mathrm{H}-3), 4.10$ (1 H, dd, J 9.5, 9.5 Hz, H-6), 4.07-4.40 (6 H, m, H-1, H-2 and $2 \times$ $\mathrm{OCH}_{2} \mathrm{CH}_{2} \mathrm{CHS}$ ), 4.58-4.73 (6 H, m, H-5 and $2.5 \mathrm{AB}$ systems of $\left.\mathrm{OCH}_{2} \mathrm{Ph}\right), 4.82-5.03$ (9 H, m, H-4 and $4 \times \mathrm{OCH}_{2} \mathrm{Ph}$ ), 5.09, 5.11 $\left(1 \mathrm{H},{ }^{2} J_{\mathrm{AB}} 11.9 \mathrm{~Hz},{ }^{3} J_{\mathrm{HP}} 7.0 \mathrm{~Hz}, 0.5 \mathrm{ABX}\right.$ system of $\left.\mathrm{POCH}_{2} \mathrm{Ph}\right)$, 6.95-6.97 (2 H, m, Ph), 7.09-7.40 (33 H, m, Ph); ${ }^{13} \mathrm{C} \mathrm{NMR}$ $\left(\mathrm{CDCl}_{3}, 100 \mathrm{MHz}\right) \delta 42.34\left(2 \times \mathrm{CH}_{3}\right), 54.03\left({ }^{3} J_{\mathrm{CP}} 7.7 \mathrm{~Hz}\right.$, $\left.\mathrm{POCH}_{2} \mathrm{CH}_{2} \mathrm{~S}\right), 54.20\left({ }^{3} J_{\mathrm{CP}} 7.7 \mathrm{~Hz}, \mathrm{POCH}_{2} \mathrm{CH}_{2} \mathrm{~S}\right), 61.16-61.24$ (overlapping signals with ${ }^{2} J_{\mathrm{CP}}$ couplings, $\mathrm{POCH}_{2} \mathrm{CH}_{2} \mathrm{~S}$ ), 69.1469.55 (overlapping signals with ${ }^{2} J_{\mathrm{CP}}$ couplings, $\mathrm{POCH}_{2} \mathrm{Ph}$ ), $72.64\left(\mathrm{OCH}_{2} \mathrm{Ph}\right), 74.75\left(\mathrm{OCH}_{2} \mathrm{Ph}\right), 75.08\left(\mathrm{OCH}_{2} \mathrm{Ph}\right), 75.19(\mathrm{C}-2)$, 77.78-78.12 (overlapping signals with $J_{\mathrm{CP}}$ couplings, C-1, C-3, C-4 and C-6), 78.81 (C-5), 127.32-128.36 ( $\mathrm{CH}$ of $\mathrm{Ph}$ ), 135.51 $\left({ }^{3} J_{\mathrm{CP}} 7.4 \mathrm{~Hz}\right.$, ipso-C of $\mathrm{POCH}_{2} \mathrm{Ph}$ ), 135.98-136.06 (overlapping signals with ${ }^{3} J_{\mathrm{CP}}$ couplings, $3 \times$ ipso-C of $\left.\mathrm{POCH}_{2} \mathrm{Ph}\right), 137.53$ (ipso-C of $\mathrm{OCH}_{2} \mathrm{Ph}$ ), 138.13 (ipso-C of $\mathrm{OCH}_{2} \mathrm{Ph}$ ), 138.19 (ipso-C of $\left.\mathrm{OCH}_{2} \mathrm{Ph}\right) ;{ }^{31} \mathrm{P}$ NMR $\left(\mathrm{CDCl}_{3}, 162 \mathrm{MHz}\right) \delta-3.37$ (1 P), -1.94 (1 P), -1.59 (1 P); HRMS ( $m / z)[M+N a]^{+}$calcd. for $\mathrm{C}_{61} \mathrm{H}_{69} \mathrm{O}_{19} \mathrm{P}_{3} \mathrm{~S}_{2}$; 1285.2980; found 1285.3011 .

D-1-Diphospho-myo-inositol 4,5-bisphosphate (1). Compound $3(63 \mathrm{mg}, 50 \mu \mathrm{mol})$ was dissolved in dry $\mathrm{CDCl}_{3}(1.5$ $\mathrm{mL}$ ) and the solution was transferred to an NMR tube. $\mathrm{A}^{31} \mathrm{P}$ NMR spectrum $\left({ }^{1} \mathrm{H}\right.$ decoupled) showed three peaks as 
described above. DBU ( $30 \mu \mathrm{L}, 200 \mu \mathrm{mol})$, followed by BSTFA (53 $\mu \mathrm{L}, 200 \mu \mathrm{mol})$ was added and the sample was shaken to mix the liquids. ${ }^{31} \mathrm{P}$ NMR spectrum taken after $1 \mathrm{~h}$ now showed three peaks: $\delta-1.84(1 \mathrm{P}),-2.20(1 \mathrm{P})$ and $-18.10(1$ $\mathrm{P})$, this last signal corresponding to the bis-silylated phosphate triester at $O-1$. Methanol $(100 \mu \mathrm{L})$ was added and the tube was shaken again. After $10 \mathrm{~min}$, TFA $(15 \mu \mathrm{L}, 200 \mu \mathrm{mol})$ was added and the solution was concentrated by evaporation under reduced pressure, then thoroughly dried under vacuum. A ${ }^{31} \mathrm{P}$ NMR spectrum $\left(\mathrm{CDCl}_{3}\right)$ of the residue showed that the silyl groups were completely cleaved, with three peaks at $\delta-0.18(1 \mathrm{P}, \mathrm{P}-1),-2.23(1 \mathrm{P})$ and $-2.45(1 \mathrm{P})$. To this residue was added 5-phenyl- $1 H$-tetrazole $(20 \mathrm{mg}, 137 \mu \mathrm{mol})$. Then, under argon, dry dichloromethane $(2 \mathrm{~mL})$ followed by bis(benzyloxy)diisopropylaminophosphine $(30 \mu \mathrm{L}, 89 \mu \mathrm{mol})$ were added. The mixture was stirred under argon for $45 \mathrm{~min}$, after which time a ${ }^{31} \mathrm{P}$ NMR spectrum of a sample $\left(\mathrm{CDCl}_{3}\right.$ added) showed major peaks at $\delta 127.24\left({ }^{2} J_{\mathrm{PP}} 4.2 \mathrm{~Hz}, \mathrm{P}-1_{\beta}\right)$, 7.59 (H-phosphonate by-product from hydrolysis of excess $\mathrm{P}(\mathrm{III})$ reagent), -2.22 and -2.41 (P-4 and P-5) and $-10.26\left({ }^{2} J_{\mathrm{PP}}\right.$ $\left.4.2 \mathrm{~Hz}, \mathrm{P}-1_{\alpha}\right)$. The solution was cooled to $-78{ }^{\circ} \mathrm{C}$ and $m$ CPBA $(70 \%, 25 \mathrm{mg}, 100 \mu \mathrm{mol})$ was added. After $5 \mathrm{~min}$, the solution was allowed to warm to room temperature, then concentrated under reduced pressure (no heat). A ${ }^{31} \mathrm{P}$ NMR spectrum of the residue now showed peaks at $\delta 7.62$ ( $\mathrm{H}$-phosphonate byproduct), -2.28 and -2.52 (P-4 and P-5) -11.97 (d, ${ }^{2} J_{\mathrm{PP}} 14.7$ $\left.\mathrm{Hz}, \mathrm{P}-1_{\beta}\right)$ and $-13.69\left(\mathrm{~d},{ }^{2} J_{\mathrm{PP}} 14.7 \mathrm{~Hz}, \mathrm{P}-1_{\alpha}\right)$. This residue was purified by flash chromatography on silica (methanol in ethyl acetate, 0 to $20 \%$ ) giving 4 as a colourless oil (59 mg, 45 $\mu \mathrm{mol}, 90 \%$ ); TLC (ethyl acetate: methanol 10:1): $R_{\mathrm{f}}=0.30$; ${ }^{31} \mathrm{P}$ NMR $\left(\mathrm{CDCl}_{3}, 162 \mathrm{MHz},{ }^{1} \mathrm{H}\right.$-decoupled $) \delta-1.75(1 \mathrm{P}, \mathrm{s})$, $-2.35(1 \mathrm{P}, \mathrm{s}),-11.08$ (1 P, broad s, P-1 $\left.{ }_{\beta}\right),-12.32$ (1 P, broad s, $\left.\mathrm{P}-1_{\alpha}\right)$; HRMS $(\mathrm{m} / \mathrm{z})[\mathrm{M}+\mathrm{Na}]^{+}$calcd. for $\mathrm{C}_{69} \mathrm{H}_{70} \mathrm{O}_{18} \mathrm{P}_{4}$; 1333.3405; found 1333.3377. In earlier trials, this material had been found to be unstable after flash chromatography; a portion of it was therefore deprotected immediately as follows.

Compound 4 (37 mg, $28 \mu \mathrm{mol})$ was dissolved in methanol $(4 \mathrm{~mL})$ and deionised water $(1 \mathrm{~mL})$. Powdered $\mathrm{NaHCO}_{3}(14$ $\mathrm{mg}, 168 \mu \mathrm{mol})$ was added followed by $\mathrm{Pd}(\mathrm{OH})_{2} / \mathrm{C}(30 \mathrm{mg})$. The suspension was stirred vigorously under $\mathrm{H}_{2}$ (balloon) for $24 \mathrm{~h}$, after which time more water $(4 \mathrm{~mL})$ was added. A fresh balloon of $\mathrm{H}_{2}$ was attached and stirring was continued for a further $72 \mathrm{~h}$. The catalyst was then removed by filtration through a PTFE filter, giving a colourless solution, which was concentrated under reduced pressure to give a solid white residue. Analysis of this residue by ${ }^{31} \mathrm{P}$ and ${ }^{1} \mathrm{H}$ NMR in $\mathrm{D}_{2} \mathrm{O}$ showed that deprotection was complete. The residue was purified by anion-exchange chromatography on Q-Sepharose Fast Flow resin, eluting with a gradient of 0 to $1.5 \mathrm{M}$ triethylammonium bicarbonate (TEAB). The target compound 1 eluted at 70 to $77 \% 1.5 \mathrm{M}$ TEAB. Fractions containing the target were identified using the Briggs phosphate assay, combined and evaporated under reduced pressure. De-ionised water was repeatedly added and evaporated until the triethylammonium salt of $\mathbf{1}$ remained as a colourless glassy solid (14 mg, $16 \mu \mathrm{mol}, 57 \%$ ). This material was accurately quantified using total phosphate assay ${ }^{37}$ before biological evaluation. For ${ }^{31} \mathrm{P}$ and ${ }^{1} \mathrm{H}$ NMR analysis of 1 , a small amount of EDTA (sodium salt, approx. $0.1 \mathrm{mg}$ ) was added to a sample of $1\left(2.0 \mu\right.$ mole in $\left.0.4 \mathrm{~mL}_{2} \mathrm{O}\right)$ to give sharper signals. This NMR sample containing EDTA was kept as the solution in $\mathrm{D}_{2} \mathrm{O}$ for $>1$ year at $4{ }^{\circ} \mathrm{C}$ with no sign of deterioration. ${ }^{1} \mathrm{H}$ NMR $\left(\mathrm{D}_{2} \mathrm{O}, 500 \mathrm{MHz}\right.$, EDTA added $) \delta 3.77(1 \mathrm{H}, \mathrm{dd}, J$ 9.8, $2.9 \mathrm{~Hz}, \mathrm{H}-3), 3.95(1 \mathrm{H}, \mathrm{t}, J$ 9.6 Hz, H-6), $4.08(1 \mathrm{H}$, apparent q, $J 9.1 \mathrm{~Hz}, \mathrm{H}-5), 4.15(1 \mathrm{H}, \mathrm{ddd}, J 9.9,8.3,2.8 \mathrm{~Hz}, \mathrm{H}-1)$, $4.32(1 \mathrm{H}$, apparent q, $J 9.4 \mathrm{~Hz}, \mathrm{H}-4), 4.35(1 \mathrm{H}$, apparent $\mathrm{t}, J$ $2.8 \mathrm{~Hz}, \mathrm{H}-2) ;{ }^{13} \mathrm{C}$ NMR $\left(\mathrm{D}_{2} \mathrm{O}, 101 \mathrm{MHz}\right) \delta 70.15$ and 70.31 (C-2 and C-3), 70.88 (C-6), $76.28\left({ }^{2} J_{\mathrm{CP}} 5.6 \mathrm{~Hz}, \mathrm{C}-1\right), 76.82$ (with $J_{\mathrm{CP}}$ couplings, C-4) and 78.11 (with $J_{\mathrm{CP}}$ couplings, C-5); ${ }^{31} \mathrm{P}$ NMR $\left(\mathrm{D}_{2} \mathrm{O}, 202 \mathrm{MHz}\right.$, EDTA added, ${ }^{1} \mathrm{H}$-decoupled) $\delta 1.11(1 \mathrm{P}), 0.45$ (1 P), -10.48 (1 P, d, J $20.9 \mathrm{~Hz}, \mathrm{P}-1_{\beta}$ ), -11.96 (d, J $20.9 \mathrm{~Hz}, \mathrm{P}-$ $\left.1_{\alpha}\right) ;{ }^{31} \mathrm{P}$ NMR $\left(\mathrm{D}_{2} \mathrm{O}, 162 \mathrm{MHz}\right.$, EDTA added, ${ }^{1} \mathrm{H}$-coupled) $\delta$ $1.13\left(1 \mathrm{P}, \mathrm{d},{ }^{3} J_{\mathrm{HP}} 8.8 \mathrm{~Hz}\right), 0.47\left(1 \mathrm{P}, \mathrm{d},{ }^{3} J_{\mathrm{HP}} 8.9 \mathrm{~Hz}\right),-10.46(1$ $\left.\mathrm{P}, \mathrm{d},{ }^{2} J_{\mathrm{PP}} 20.5 \mathrm{~Hz}, \mathrm{P}-1_{\beta}\right),-11.94\left(1 \mathrm{P}, \mathrm{dd},{ }^{2} J_{\mathrm{PP}} 20.5,{ }^{3} J_{\mathrm{HP}} 8.3 \mathrm{~Hz}\right.$, $\left.\mathrm{P}-1_{\alpha}\right)$; HRMS $(\mathrm{m} / \mathrm{z}) \mathrm{M}^{-}$calcd. for $\mathrm{C}_{6} \mathrm{H}_{16} \mathrm{O}_{18} \mathrm{P}_{4} ; 498.9209$; found 498.9214.

Molecular docking of 1-PP-Ins(4,5) $\mathrm{P}_{2}(1)$ into type $1 \operatorname{InsP}_{3}$ receptor. Molecular docking experiments were carried out using the X-ray crystal structure of the $N$-terminal IBC of type 1 InsP $_{3}$ receptor in complex with $\operatorname{Ins}(1,4,5) \mathrm{P}_{3}(1 \mathrm{~N} 4 \mathrm{~K}) .^{18}$ Docking methods were optimised by docking flexible models of Ins $(1,4,5) \mathrm{P}_{3}$ into the $1 \mathrm{~N} 4 \mathrm{~K}$ structure using GOLD $^{38}$ (version 5.6, CCDC). In the most successful protocol, the binding site was defined as a sphere of $6 \AA$ radius centred on the centroid of bound $\operatorname{Ins}(1,4,5) \mathrm{P}_{3}$ and two water molecules (waters 1139 and 1198) were included in the docking protocol. These water molecules were toggled on and off and allowed to spin in the docking runs. ${ }^{39}$ The ligand was docked 100 times using the GoldScore scoring function, and genetic algorithm settings for very flexible ligands were used. This method accurately reproduced the observed pose of bound $\operatorname{Ins}(1,4,5) \mathrm{P}_{3}$ in $1 \mathrm{~N} 4 \mathrm{~K}$; the ten highest scoring poses all closely resembled the conformation of bound Ins $(1,4,5) \mathrm{P}_{3}$ (mean RMSD $0.58 \AA$ ). When 1-PP-Ins $(4,5) \mathrm{P}_{2}(1)$ was docked using the same protocol, the highest-scoring poses were very similar to the bound conformation of $\operatorname{Ins}(1,4,5) \mathrm{P}_{3}$ but often showed additional interactions of the 1-beta-phosphate group with residues in the binding site. More details are given in the ESI. $\dagger$

Assays of $\mathrm{InsP}_{3}$ receptor activity. $\mathrm{Ca}^{2+}$ release from the intracellular stores of permeabilised DT40 cells expressing rat type $1 \mathrm{InsP}_{3}$ receptors was measured in cytosol-like medium (CLM) using a low-affinity fluorescent $\mathrm{Ca}^{2+}$ indicator trapped within the endoplasmic reticulum as previously reported. ${ }^{40}$ Equilibrium competition binding of $\left[{ }^{3} \mathrm{H}\right]-\mathrm{InsP}_{3}(1.5 \mathrm{nM}, 19.3$ $\mathrm{Ci} \mathrm{mmol}^{-1}$ ) to membranes prepared from insect Sf9 cells expressing rat type $1 \mathrm{InsP}_{3}$ receptors was determined in CLM at $4{ }^{\circ} \mathrm{C}$. Bound and free ligand were separated by centrifugation and non-specific binding was determined by addition of 10 $\mu \mathrm{M}$ InsP $_{3}$.

DIPP purification. cDNAs for all DIPPs were kind gifts from the Structural Genomics Consortium, Stockholm. cDNAs were 
modified as necessary in order to represent the full-length constructs, cloned into pET28a (+) and expressed as $N$-terminally His-tagged proteins. All proteins were expressed in BL21 (DE3) T1R pRARE2 at $18^{\circ} \mathrm{C}$ overnight and purified by the Protein Science Facility (PSF) at the Karolinska Institute, Stockholm. Briefly, the proteins were first purified over a HisTrap HP column (GE Healthcare), followed by thrombin cleavage of the $N$-terminal His-tag. After removal of the His-tag through a second run over a HisTrap HP column, the proteins were further purified by gel filtration using a HiLoad 16/60 Superdex 75 column (GE Healthcare).

Enzyme activity assay (DIPPs). Activity of DIPPs with a panel of potential substrates (1-PP-InsP $\mathrm{P}_{5}, 5$-PP-InsP $\mathrm{P}_{5}, 1$-PPIns $(4,5) \mathrm{P}_{2}(1), \mathrm{Ap}_{3} \mathrm{~A}$, and $\mathrm{Ap}_{5} \mathrm{~A}$ (Sigma Aldrich)) and control compounds (1-PCP-InsP $\mathrm{P}_{5}$ and 5 -PCP-InsP $\mathrm{P}_{5}$ ) was assessed in technical triplicates in reaction buffer $(100 \mathrm{mM}$ Tris acetate, $\mathrm{pH}$ 7.5, $40 \mathrm{mM} \mathrm{NaCl}, 1 \mathrm{mM}$ DTT) containing either $1 \mathrm{mM} \mathrm{Mg}$ acetate or $\mathrm{MnCl}_{2}$. Following an incubation time of $20 \mathrm{~min}$ at room temperature with shaking, the formed inorganic phosphate was detected through addition of malachite green reagent. ${ }^{41}$ After an additional 15 min incubation with shaking, absorbance at $630 \mathrm{~nm}$ was read using a Hidex Sense plate reader.

Differential scanning fluorimetry (DSF). $\mathrm{DSF}^{42}$ was performed with $5 \mu \mathrm{M}$ purified protein in $25 \mathrm{mM}$ HEPES $\mathrm{pH}$ 7.5, $100 \mathrm{mM} \mathrm{NaCl}, 0.5 \mathrm{mM}$ TCEP and 5× Sypro Orange added per well of a 96-well PCR plate. Substrates and substrate analogues were dissolved in water and diluted 1:10 in the assay mixture. The heat denaturation curves with a temperature increase of $1{ }^{\circ} \mathrm{C} \min ^{-1}$ from $25{ }^{\circ} \mathrm{C}$ to $95{ }^{\circ} \mathrm{C}$ were recorded on a CFX96 real-time PCR machine (Bio-Rad) by measuring the fluorescence of Sypro Orange with excitation and emission wavelengths of 470 and $570 \mathrm{~nm}$, respectively. The Boltzmann equation was used to analyse the denaturation curves in GraphPad Prism. The determined melting temperature $\left(T_{\mathrm{m}}\right)$ is the inflection point of the sigmoidal denaturation curve.

\section{Conflicts of interest}

There are no conflicts to declare.

\section{Acknowledgements}

BVLP (grant 101010) and CWT (grant 101844) are Wellcome Trust Senior Investigators. We also acknowledge funding by the Swedish Pain Relief Foundation and the Swedish Cancer Society (TH). We thank Dr Stephen B. Shears for helpful discussions on the enzymes that are known to synthesise PPInsPs.

\section{Notes and references}

1 M. P. Thomas, S. J. Mills and B. V. L. Potter, Angew. Chem., Int. Ed., 2016, 55, 1614-1650.

2 C. W. Taylor and S. C. Tovey, Cold Spring Harbor Perspect. Biol., 2010, 2, a004010.

3 M. P. Thomas and B. V. L. Potter, FEBS J., 2014, 281, 14-33.
4 S. B. Shears, J. Cell. Physiol., 2018, 233, 1897-1912.

5 S. G. Thota and R. Bhandari, J. Biosci., 2015, 40, 593-605; M. S. C. Wilson, T. M. Livermore and A. Saiardi, Biochem. J., 2013, 452, 369-379.

6 K. J. Alzayady, L. W. Wang, R. Chandrasekhar, L. E. Wagner, F. Van Petegem and D. I. Yule, Sci. Signaling, 2016, 9, ra35.

7 K. M. Sureshan, A. M. Riley, M. P. Thomas, S. C. Tovey, C. W. Taylor and B. V. L. Potter, J. Med. Chem., 2012, 55, 1706-1720.

8 B. V. L. Potter and D. Lampe, Angew. Chem., Int. Ed. Engl., 1995, 34, 1933-1972.

9 T. M. Livermore, C. Azevedo, B. Kolozsvari, M. S. C. Wilson and A. Saiardi, Biochem. Soc. Trans., 2016, 44, 253-259.

10 H. B. R. Luo, Y. E. Huang, J. M. C. Chen, A. Saiardi, M. Iijima, K. Q. Ye, Y. F. Huang, E. Nagata, P. Devreotes and S. H. Snyder, Cell, 2003, 114, 559-572; A. Chakraborty, M. A. Koldobskiy, N. T. Bello, M. Maxwell, J. J. Potter, K. R. Juluri, D. Maag, S. Kim, A. S. Huang, M. J. Dailey, M. Saleh, A. M. Snowman, T. H. Moran, E. Mezey and S. H. Snyder, Cell, 2010, 143, 897-910.

11 N. A. Gokhale, A. Zaremba, A. K. Janoshazi, J. D. Weaver and S. B. Shears, Biochem. J., 2013, 453, 413-426.

12 R. Wild, R. Gerasimaite, J. Y. Jung, V. Truffault, I. Pavlovic, A. Schmidt, A. Saiardi, H. J. Jessen, Y. Poirier, M. Hothorn and A. Mayer, Science, 2016, 352, 986-990.

13 R. Gerasimaite, I. Pavlovic, S. Capolicchio, A. Hofer, A. Schmidt, H. J. Jessen and A. Mayer, ACS Chem. Biol., 2017, 12, 648-653.

14 A. Saiardi, R. Bhandari, A. C. Resnick, A. M. Snowman and S. H. Snyder, Science, 2004, 306, 2101-2105; R. Bhandari, A. Saiardi, Y. Ahmadibeni, A. M. Snowman, A. C. Resnick, T. Z. Kristiansen, H. Molina, A. Pandey, J. K. Werner Jr., K. R. Juluri, Y. Xu, G. D. Prestwich, K. Parang and S. H. Snyder, Proc. Natl. Acad. Sci. U. S. A., 2007, 104, 15305-15310.

15 R. S. Kilari, J. D. Weaver, S. B. Shears and S. T. Safrany, FEBS Lett., 2013, 587, 3464-3470.

16 M. Takahashi, K. Tanzawa and S. Takahashi, J. Biol. Chem., 1994, 269, 369-372.

17 H. Hotoda, K. Murayama, S. Miyamoto, Y. Iwata, M. Takahashi, Y. Kawase, K. Tanzawa and M. Kaneko, Biochemistry, 1999, 38, 9234-9241.

18 I. Bosanac, J. R. Alattia, T. K. Mal, J. Chan, S. Talarico, F. K. Tong, K. I. Tong, F. Yoshikawa, T. Furuichi, M. Iwai, T. Michikawa, K. Mikoshiba and M. Ikura, Nature, 2002, 420, 696-700.

19 T. Desai, J. Gigg, R. Gigg and E. Martin-Zamora, Carbohydr. Res., 1994, 262, 59-77.

20 Z. Y. Lim, J. W. Thuring, A. B. Holmes, M. Manifava and N. T. Ktistakis, J. Chem. Soc., Perkin Trans. 1, 2002, 1067-1075.

21 S. Capolicchio, D. T. Thakor, A. Linden and H. J. Jessen, Angew. Chem., Int. Ed., 2013, 52, 6912-6916; S. Capolicchio, H. C. Wang, D. T. Thakor, S. B. Shears and H. J. Jessen, Angew. Chem., Int. Ed., 2014, 53, 9508-9511.

22 H. C. Wang, H. Y. Godage, A. M. Riley, J. D. Weaver, S. B. Shears and B. V. L. Potter, Chem. Biol., 2014, 21, 689-699. 
23 E. R. Wijsman, O. van den Berg, E. Kuyl-Yeheskiely, G. A. van der Marel and J. H. van Boom, Recl. Trav. Chim. PaysBas, 1994, 113, 337-338; S. B. Engelsma, N. J. Meeuwenoord, H. S. Overkleeft, G. A. van der Marel and D. V. Filippov, Angew. Chem., Int. Ed., 2017, 56, 2955-2959.

24 B. Bradshaw, A. Dinsmore, W. Ajana, D. Collison, C. D. Garner and J. A. Joule, J. Chem. Soc., Perkin Trans. 1, 2001, 3239-3244.

25 I. Pavlovic, D. T. Thakor, L. Bigler, M. S. C. Wilson, D. Laha, G. Schaaf, A. Saiardi and H. J. Jessen, Angew. Chem., Int. Ed., 2015, 54, 9622-9626.

26 V. Lafont, A. A. Armstrong, H. Ohtaka, Y. Kiso, L. M. Amzel and E. Freire, Chem. Biol. Drug Des., 2007, 69, 413-422; E. Freire, Drug Discovery Today, 2008, 13, 869-874.

27 M. Wu, L. S. Chong, S. Capolicchio, H. J. Jessen, A. C. Resnick and D. Fiedler, Angew. Chem., Int. Ed., 2014, 53, 7192-7197.

28 M. Wu, B. E. Dul, A. J. Trevisan and D. Fiedler, Chem. Sci., 2013, 4, 405-410.

29 N. R. Leslie, A. G. McLennan and S. T. Safrany, BMC Biochem., 2002, 3, 20.

30 T. Zhang, J. J. Caffrey and S. B. Shears, FEBS Lett., 2001, 494, 208-212; A. Saiardi, E. Nagata, H. B. R. Luo, A. Sawa, X. J. Luo, A. M. Snowman and S. H. Snyder, Proc. Natl. Acad. Sci. U. S. A., 2001, 98, 2306-2311.

31 J. Monserrate and J. York, Curr. Opin. Cell Biol., 2010, 22, 365-373.

32 H. Wang, J. R. Falck, T. M. Hall and S. B. Shears, Nat. Chem. Biol., 2012, 8, 111-116.
33 E. Dubois, B. Scherens, F. Vierendeels, M. M. W. Ho, F. Messenguy and S. B. Shears, J. Biol. Chem., 2002, 277, 23755-23763.

34 A. M. Seeds, R. J. Bastidas and J. D. York, J. Biol. Chem., 2005, 280, 27654-27661.

35 H. C. Wang, E. F. DeRose, R. E. London and S. B. Shears, Nat. Commun., 2014, 5, 4178.

36 A. M. Riley, H. C. Wang, S. B. Shears and B. V. L. Potter, Chem. Commun., 2015, 51, 12605-12608.

37 B. N. Ames and D. T. Dubin, J. Biol. Chem., 1960, 235, 769-775.

38 G. Jones, P. Willett, R. C. Glen, A. R. Leach and R. Taylor, J. Mol. Biol., 1997, 267, 727-748.

39 M. L. Verdonk, G. Chessari, J. C. Cole, M. J. Hartshorn, C. W. Murray, J. W. M. Nissink, R. D. Taylor and R. Taylor, J. Med. Chem., 2005, 48, 6504-6515.

40 A. M. Vibhute, V. Konieczny, C. W. Taylor and K. M. Sureshan, Org. Biomol. Chem., 2015, 13, 6698-6710.

41 A. A. Baykov, O. A. Evtushenko and S. M. Avaeva, Anal. Biochem., 1988, 171, 266-270.

42 F. H. Niesen, H. Berglund and M. Vedadi, Nat. Protoc., 2007, 2, 2212-2221.

43 W. Nakanishi, K. Kikuchi, T. Inoue, K. Hirose, M. Iino and T. Nagano, Bioorg. Med. Chem. Lett., 2002, 12, 911-913.

44 H. Saleem, S. C. Tovey, T. Rahman, A. M. Riley, B. V. L. Potter and C. W. Taylor, PLoS One, 2013, 8, e54877. 